\title{
The impact of educational policies in higher education in the context of sustainable development
}

\author{
ŞtefanŢălu ${ }^{1, *}$, and Anton Nazarov ${ }^{2}$ \\ ${ }^{1}$ Technical University of Cluj-Napoca, The Directorate of Research, Development and Innovation \\ Management (DMCDI), Cluj-Napoca, 400020 Cluj county, Romania \\ ${ }^{2}$ Ural State University of Economics, 8 Marta/Narodnoy Voli St. 62/45, 620144 Ekaterinburg, Russia
}

\begin{abstract}
The purpose of this study is to evaluate the impact of educational policies in higher education in the context of sustainable development and identifies agents for positive change in reorienting societies towards sustainable development. The analyses highlight different effective implementation mechanisms of government policies to progress sustainable development. Interpretive and decision-making flexibility provides a new framework and new opportunities for evaluating the concept of sustainability in various academic traditions, at different management university levels, as well as for monitoring of the educational process in universities.
\end{abstract}

\section{Introduction}

The development and modernization of a country's economy, to ensure macroeconomic balance and socio-political stability in any society, is a process with dynamic features that derive from the structure of the economy, performance, and implicitly, economic potential, readiness, and multiple opportunities to improve the workforce [1].

Higher education institutions are the essential tool of technological innovation with the role of overcoming today's global challenges and aim to prepare citizens capable of building a fairer and more open society, with an ethical-moral vision and the knowledge necessary to ensure the quality of life of future generations [2].

In the international scientific context of current higher education, which has multiple implications on multiple levels: economic, psycho-social, educational, cultural, political, it is highlighted that in our society we need a new man with extensive knowledge of practices, aware of the challenges that may arise in his professional life, who is fully aware of the complex and dynamic evolution of society and who has the necessary skills to deal with societal aspects of technology and take advantage of career opportunities [3].

It is known that the concept of sustainable education involves active academic participation to create economic, social, and environmental programs improving life standards, generating empowerment, and respecting interdependence [2, 4].

\footnotetext{
* Corresponding author: stefan_ta@yahoo.com
} 
Higher education at the end of the last century developed the concept of sustainable development (as well as its three main components which include economic growth, social development, and environmental balance) to analyze, develop and evaluate relevant policies and initiatives needed for it to become operational [2].

In this sense, the development of new legislative and sectoral initiatives allowed the identification of corrective measures and the estimation of the costs of programmatic interventions [2].

The World Commission on Environment and Development (WCED), established in 1983, published a report entitled "Our Common Future" in 1987, which identified, explained, and developed guidelines for sustainable development that was recognized as the "Brundtland Report" after the Commission President, Norwegian Prime Minister Gro Harlem Brundtland. On the other hand, sustainable development is a strategy that is citizenoriented and focuses on innovation, optimism, resilience, and confidence that the state serves the needs of every citizen, fairly and efficiently [2].

In the literature, there are over 100 definitions of the term "sustainable development", which is a synthesis between the aspirations of the free-born citizen, the society in which he lives, and which also defines the multilateral context that allows self-realization [2].

In this context, man is the central actor who seeks an individual social balance and reasonably favorable conditions to achieve on multiple levels.

These favorable conditions are influenced both by the society that should support and motivate it, as well as by the socio-economic-political environment (at national, European, and global levels) through which it is found and can be achieved.

In the context of sustainable development, the policy and role of the state are to provide a framework and support for achieving this balance with a horizon of time, both for contemporary citizens and for future generations [5].

The initial idea that the term sustainability sought to express is that living generations do not have the moral right to compromise or diminish, in terms of their interest in the welfare and unlimited comfort, the chances of future generations to have the necessary resources ensuring a decent and prosperous life.

This initial meaning, although it is a deep and generous idea, insufficiently clearly outlined, also has a series of factual counter-arguments, which express, quite rightly, reservations about the criteria for assessing the "chances" of future generations [6].

On the other hand, sustainable development is a normative concept that incorporates the standards of judgment and behavior, to be respected, as the human community society seeks to meet its needs for survival and well-being.

Smart-education by approaching unitary scientific knowledge (extrinsic and intrinsic) is the basis of the educational paradigm - "lifelong learning", for a future society - the society of consciousness, truth, morality, and spirit at all levels and in all social contexts [7-9].

Smart education based on ethics is a continuous process throughout life, which prepares young generations for the challenges of the future by encouraging constructive critical thinking, meritocracy, curiosity, innovation, conduct, and emancipation [10].

Smart-education suggests a global approach to modeling activity, in which the acquisition of knowledge, the formation of intellectual abilities, emotional availability, practical skills, professionalization, etc. do not represent finalities, but conditions for the elaboration of personal competences of self-realization through creation [11-13].

Thus, a transdisciplinary approach to intelligent education will contribute through its positive valences to the creation of values and attitudes that can be formed in students, such as - complex and creative thinking; - high degree of objectivity in knowing the reality; • system of methods of unitary knowledge of reality; - scientific language specific to integrated knowledge; • appropriate behavior in solving significant situations [14-18]. 


\section{Research methodology}

In this study, a set of questions was proposed:

1. What is the impact of educational policies in higher education to face the new complex challenges caused by globalization and the development of education in the current socio-economic-political conditions?

2. How to accelerate government action to increase the active involvement of all relevant societal factors and actions motivated by ensuring the harmonious combination of the three dimensions of sustainable development for the transformation of in a sustainable society?

3. How can the democratization of the decision-making process on sustainable development in higher education be made more efficient?

In this study in the framework of European policy and in the current priorities of the European Commission, the authors assessed the situation and identifying the most relevant concerns about smart education for sustainable development.

\section{Discussion}

As the number of strategic dimensions and corresponding political initiatives increases it is conceptualized a framework of thinking that once taken over and assimilated by the citizen, will allow the creation of a more equitable society, ensuring a fair and acceptable transition for all from a social point of view, in the spirit of inclusion and solidarity and to cope with the changes brought about by current global, regional and national problems.

In this sense, the care of the state towards the citizen and the respect of the citizen towards the institutions, towards his neighbor, moral values, and cultural and ethnic diversity will lead to a sustainable society.

Obstacles to a graceful transition to sustainability, in any form, are not technological, they are social, political, and psychological. At the same time, there is the possibility of becoming immobilized by information overload.

Both the European Union and the member states must take social implications into account from the outset and apply all relevant educational policies to address this global challenge.

New initiatives are being prepared to comprehensively address the social and economic costs of modernization determined by smart-education policies for sustainable development. While sustainability has a clear meaning in particular contexts, as an objective it is sometimes vague because education for sustainability contradicts the dominant conceptions of education: it presupposes a kind of intellectual exclusivity and determinism that opposes the ideas of emancipation, local knowledge, democracy, and selfdetermination.

The core value of sustainability, as well as basic knowledge, are in a various variable, unstable and questionable contexts that can make the concept of sustainability unusable or reduce it to a rhetorical tool, giving it strength if used in a clear and operative context. We will analyze this extraordinary educational potential and look for ways to find standards for the integration of sustainability in higher education in a way that does not standardize the realities and that can and should be exploited by higher education institutions.

The purpose of smart education for sustainable development is the development of a platform for the acquisition of new knowledge and is achieved through the following components: a smart-university, a smart-teacher, and a smart-student.

The role of education - in general - and that of higher education - in particular - is crucial in implementing the concept of sustainable development throughout society. Thus, universities must allocate resources intelligently to become sustainable and provide 
students with an experience living in a sustainable environment. They must be the catalyst for the necessary changes at the level of the whole society and their graduates must be the tools through which the transformation of the whole society, in the direction of sustainable development. From a regional and national perspective, there are multiple perspectives on sustainability, education for sustainable development, and education for sustainability, as well as on how professors/teachers should interpret these ideas.

The potential of a smart university is to be an agent of change, accelerating the transition to sustainability and depends on several factors that include the position, structure, and organization of higher education in society and the sustainability issues specific to the area and the opportunities enjoyed by a particular community or region. In general, a smart university is oriented towards connections outside the university (extrauniversity), interdisciplinary approaches, and partnerships for the continuous improvement of decision-makers and students, but related to environmental, cultural, and political constraints.

A smart university will support projects, partnerships, and educational opportunities to provide the acquisition and development of basic and key competencies, to promote socioeducational and personal development, professional development, cooperation in science, technology, but also active participation in the life of society. This informational conglomerate also includes multilingual skills, entrepreneurial thinking, critical thinking, and creativity, but also complementary skills in artificial intelligence or other social skills. Teachers and students must be prepared with informational values to analyze criticisms of science and technical reason, to avoid the trap of superficial understanding itself, which can serve certain norms, values, and predominant interests, and to identify the existence of conflicting norms, values, and interests.

Smart specialization involves a complex effort to explore and select priority operational areas of investment with economic and innovative potential [9-11]. Based on correctly targeted investments and the accumulation of an important human resource, they have the potential to offer concentrations of competitive commercial activity, with a regional or national scope. These areas of smart specialization have both strictly scientific and technological fields. Smart specialization involves some objectives: $\bullet$ stimulating a certain type of economic behavior, with regional or global scope and orientation; $\bullet$ understanding the social impact of science, technology, and economic activities in the relevant sectors; • modern interdisciplinary research and development with applications beyond traditional borders. The smart specialization process, which involves gradual learning, has an iterative and dynamic nature, which involves the permanent collection and analysis of data at the regional and national level, and contains a monitoring mechanism inserted in the strategic cycle, to set in motion an effective training and other economic and scientific sectors.

Rewarding excellence in teaching-research are essential and must be correlated with the development of students' skills through a multilateral approach by a) developing and implementing innovative strategies and high-quality assessment to reward and stimulate excellence in teaching; b) training academic staff with new and innovative teaching and evaluation methods and techniques, with transdisciplinary approaches, which connect education - research - innovation, with transparency and professionalism. The results of these effective, efficient, and sustainable funding models through systemic government policies at the system level will increase relevance for the community.

The implementation of government strategies involves compliance with the following principles: - assuming strategic priorities and a firm long - term commitment to ensuring resources in the interests of society, for the well - being of the citizen; - multilateral managerial coordination between actors, policies and programs, both horizontally (unitary coordination of policies at national level developed by relevant agencies and ministries) and vertically (efficient planning at all stages of the strategic process of roles between 
responsible political institutions); - creating a strategic performance center with high performance and organizational focus to collect, analyze and quantify important data in order to provide a clear and coherent expertise throughout the public policy cycle, focusing mainly on relevance, effectiveness, efficiency, consistency and coherence and sustainability of measures; - ensuring public access to information on instruments, policies, funding opportunities and results, while respecting intellectual property.

Complex combinatorial directions of action on government policies include fiscal policies; public procurement of research and innovation; competitive financing of the public and private sectors; intellectual property; collaboration and concentration; institutional financing; human resources; as well as system governance.

\section{Conclusion}

In conclusion, by applying the fair educational policies in higher education to face the complex challenges in the current socio-economic-political conditions, it can be promoted a smart university based on creating and demonstrating alternative visions of a better future and by promoting effective action to meet the current challenges. In this way, in higher education, it is improved the quality of life of students, academics, and managers which are focused on smart learning, utility-based smart research, and a smart continuing education capable of supporting local university policies and its cultural principles.

Systematic-innovative approaches for the continuous and professional development of teachers, trainers, and mentors in the field of higher education with the application of efficient and open pedagogies with the integration of advanced digital technologies for teaching and learning are a central objective in the strategies and management styles applied in a smart-university. Improving the mechanisms for monitoring effectiveness and improving educational quality assurance through participatory and intercultural dialogue, provides concrete conditions for continuously improving the impact that a smart university has on the environment, society, and the economy, involving a diverse range of partners, to benefit from their different experiences and skills, as well as to produce visible and highquality results.

A smart university that uses adequate modern information management, which favors an educational process capable of a direct and decisive interaction both internally, within the educational system, and externally, with the non-academic society, must follow high quality and be able to develop innovative results in different cultures and subcultures of students, academics and managers.

\section{References}

1. G. Blokdyk, Sustainable development goals: a complete guide (2020)

2. B. Nataliya, V.K. Natalya, F. Viacheslav, K. Irina, S. Alexandra, I.F. Nadezhda, The Concept of smart-education for sustainable development (2018)

3. V.L. Uskov, J.P. Bakken, R.J. Howlett, L.C. Jain, Smart universities: concepts, systems, and technologies (2018)

4. M. Shanks, C.M. Stracke, O. Tveiten, Smart universities: education's digital future (2018)

5. Z.T. Zhu, Yu Ming-Hua, P. Riezebos, A research framework of smart education, 3 (2016)

6. R. Neves-Silva, G.A. Tsihrintzis, V.L. Uskov, R.J.Howlett, L.C. Jain, Smart digital futures (2014) 
7. Ş. Ţălu, Business and Management Research (AEBMR), 105, 554 (2019)

8. Ş. Ţălu, Advances in Economics, Business and Management Research (AEBMR), 138, 253 (2020)

9. A.B. Schiopoiu, D.D. Burdescu, The development of the critical thinking as strategy for transforming a traditional university into a smart university, 75, 67 (2017)

10. E. Shoikova, R. Nikolov, E. Kovatcheva, Conceptualising of smart education, 3 (4), 29 (2017)

11. S. Radosevic, A. Curaj, R. Gheorghiu, L. Andreescu, I. Wade, Advances in the theory and practice of smart specialization (2017)

12. P. McCann, F. van Oort, J. Goddard, The empirical and institutional dimensions of smart specialization (2016)

13. M. Milana, P. Rasmussen, J. Holford, Societal sustainability: The contribution of adult education to sustainable societies, 62(5), 517 (2016)

14. Ş. Țălu,Ş. Țălu, D Sobola, N. Papež, Analysis and recommendations for education process of experts in the field of scanning probe microscopy, 5 (2017)

15. Ş. Ţălu, D. Sobola, R.S. Dallaev, Advances in Economics, Business and Management Research (AEBMR), 81, (2019)

16. V.N. Yurievna, K.E. Sergeyevna, N.A. Dmitrievich, Advances in Social Science, Education and Humanities Research, 240, 685 (2018)

17. I. Lyapina, E. Sotnikova, O. Lebedeva, T. Makarova, N. Skvortsova. Smart technologies: perspectives of usage in higher education, 33(3), 454 (2019)

18. Three dimensions of smart education, 41, 47 (2015) 